Maurer School of Law: Indiana University

Digital Repository @ Maurer Law

1962

\title{
The Interplay of Planned Economy and Traditional Contract Rules in Poland
}

Wencelas J. Wagner

Indiana University School of Law

Follow this and additional works at: https://www.repository.law.indiana.edu/facpub

Part of the Comparative and Foreign Law Commons, and the Contracts Commons

\section{Recommended Citation}

Wagner, Wencelas J., "The Interplay of Planned Economy and Traditional Contract Rules in Poland" (1962). Articles by Maurer Faculty. 2369.

https://www.repository.law.indiana.edu/facpub/2369

This Article is brought to you for free and open access by the Faculty Scholarship at Digital Repository @ Maurer Law. It has been accepted for inclusion in Articles by Maurer Faculty by an authorized administrator of Digital Repository @ Maurer Law. For more information, please contact rvaughan@indiana.edu. 


\title{
The Interplay of Planned Economy and Traditional Contract Rules in Poland
}

\author{
Quite naturally, the political upheaval imposed upon the Central-
} European countries after World War II brought about important changes in their legal systems. As far as the area of "public law" is concerned, it could not be otherwise. But what was the impact of the structural developments of these states on their "private law," and particularly, on the law of contracts? ? $^{1}$

It can readily be seen that the area of matters on which individual citizens may contract is much more restricted in those countries than in the traditional legal systems. The so-called "socialist" states which are "on the way to communism" introduced as one of the first reforms of their economic structure the principle of state ownership of most means of production and business enterprises. ${ }^{2}$ The industrial and commercial life of the country, as well as the relations between the state enterprises or "socialist organizations," are based on economic planning. ${ }^{3}$ In such a situation, there is not much room for commercial transactions of importance between private individuals or enterprises. ${ }^{2}$

In spite of the fact that all communist countries have a common ideological background, and that the economic system of the Soviet

W. J. WAGner is Professor of Law, Indiana University School of Law. The author expresses his gratitude to Professor Rudolf B. Schlesinger of the Cornell Law School for his valuable criticism of the original draft of this article.

1 This article is based on the introduction to the Polish law of contracts, prepared by the author for the Fall 1961 session of the General Principles Project of the Cornell Law School and published here with the permission of that Project. The views expressed herein are exclusively those of the author. They were discussed with, but not necessarily endorsed by, other participants in the Project. Concerning the nature of the comparative research undertaken by the General Principles Project, which is supported by a Ford Foundation grant, see Schlesinger, "The Common Core of Legal Systems-An Emerging Subject of Comparative Study," in XXth Century Comparative and Conflicts Law-Legal Essays in Honor of H. E. Yntema (1961) $65 \mathrm{ff}$.

The term "socialist" is used in this article interchangeably with "communist," and pertains to countries based on planned economy.

2 The most important branches of Poland's economy were nationalized by the law of Jan. 3, 1946, Dz. U. of Feb. 5, 1946, No. 4, poz. 17, as amended.

${ }^{3}$ Economic planning was introduced by the decree of Oct. 1, 1947, Dz. U. No. 64, poz. 374 (1947). And Art. 3 of the Constitution of 1952 provided that the Republic shall "organize a planned economy on the basis of enterprises in social ownership." For some problems of such a system, see e.g., Pounds and Spulber, Eds., Resources and Planning in Eastern Europe (1957).

${ }^{4}$ In Poland, as early as 1948, 94\% of industry was nationalized. Szwejcer, Les Nationalisations en Pologne, in 14 Travaux et Recherches de l'Institut de Droit Comparé de l'Université de Paris, Les Nationalisations en France et à l'Étranger (1958) 213, 241. 
Union exerts a strong influence on all the others, there is no uniform pattern in their economic structure. As a matter of fact, differences between them are pronounced. The situation in Poland and Yugoslavia is more similar to that of the traditional economic systems than that in other communist states. Thus, contrary to many other communist countries, agricultural land in Poland has remained by and large in private hands (though larger farms were liquidated), with some degree of freedom being left to the farmers. ${ }^{5}$ Of course, they have to sell the major part of their farm products to the state. Although, in theory, such deliveries are made irı accordance with contracts concluded between the state and the producers, in fact the system amounts to a kind of tax. What remains may be used by the farmer or sold on the open market, subject-in many instances-to price regulations enacted by the state. Nevertheless in such situations the contractual relations between the parties involved are more or less similar to those existing between contracting parties in the traditional systems of law. Moreover, handicrafts and some small industrial enterprises (although heavily burdened with taxes) have been left in the hands of private individuals.

In the socialized sector, also, Polish law speaks of contracts, meaning contracts between state enterprises. But are such contracts comparable to consensual obligations in the traditional sense? Of course, "such a problem cannot be determined by labels."

Contracts in Poland of today may be concluded between three types of parties: private individuals, co-operatives, and socialist enterprises. Subject to some important qualifications to be discussed later, consensual obligations among members of the first group do not differ from those concluded in the traditional legal systems. On the other hand, contracts concluded between socialized economic units constitute a new legal institution. Besidss these two extremes, there are intermediate situations: contracts concluded between socialist entities on one part, and individuals or co-operatives on the other. Many of these belong to the first category-e.g., a co-operative purchases supplies from a government store. Some, however, are regulated by special

\footnotetext{
"Siekanowicz, "Land and Peasant in Poland," in 2 Gsovski and Grzybowski, Government, Law and Courts in the Soviet Union and Eastern Europe, (1959) 1809. In 1956,78.8\% of arable land was in the hands of individual farmers, $8.6 \%$ belonged to collective farms, and $12.6 \%$ constituted government farms. Id., at 1843 .

${ }^{\circ}$ Schlesinger, The Common Core of Legal Systems-An Emerging Subject of Comparative Study, in XXth Century Comparative and Conflicts Law-Legal Essays in Honor of Hessel E. Yntema, (1961) 65, 69. The author continues: "The fact that two institutions both are labeled 'contract,' does not make them comparable. Nor is comparability assured by superficial similarities of positive rules or of other institutional elements." And he concludes: "In functional terms, the comparability of a free contract and of a contract between plan-fulfilling state enterprises is highly problematic.
} 
rules unknown in the traditional legal systems; such as, e.g., the contract of "contractation," as will be explained below.

In foreign trade, the state or one of its corporations may enter into contracts with "capitalist" parties. In such a case, it is clear that traditional rules of contract law will apply. With reference to foreign trade, "General Conditions of Delivery of Goods" have been adopted by international agreement among the communist countries. Interestingly, these General Conditions by and large reflect traditional rules of contract law.

In the following observations about consensual obligations in Poland, the traditional contracts will be discussed first. "Contracts" among socialized economic units will then be taken up. This will be followed by a brief discussion of international contracts covered by the "General Conditions of Delivery of Goods." Provisions of the new Polish draft Civil Code on contracts between socialist organizations and on contracts of "contractation" will be reproduced, in English translation, at the end of the article. The general purpose of the present paper is to explore both the private and the socialized sectors of Polish "contract law" and to examine their comparability with traditional legal systems.

\section{Traditional Contracts}

Consensual obligations in the modern Polish state were governed by the Code of Obligations of October 27, 1933, in force as of July 1, $1934,{ }^{7}$ supplemented by the Commercial Code of June 27, 1934, in force as of the same year. ${ }^{8}$ These Polish enactments, ${ }^{9}$ the result of many years of hard work and careful drafting, were favorably received all over the world. This is what the great French legal scholar Henri Capitant stated in his preface to the French translation of the Code of Obligations:

The qualities of method and of formulation are undeniable and striking even at first sight .... (B)ecause of its precision, its clarity and the shortness of its articles, the Polish Code is much more akin to the Swiss Civil Code than to the German. It has avoided heavy and unpleasant casuistry ... We believe the work to be completely successful. ${ }^{10}$

${ }^{7}$ Dz. U.R.P. of October 28, 1933, No. 82, poz. 598.

${ }^{8}$ Dz. U.R.P. of June 30, 1934, No. 57, poz. 502, as amended.

${ }^{9}$ For details about the work of codifying Polish law, see Nagórski, "Codification of Civil Law in Poland (1918-1939)," in Studies in Polish and Comparative Law (London, 1945).

${ }_{10}$ Nagórski, "Draft of a New Civil Code for Poland," in 1 Studies of the Association of Polish Lawyers in Exile in the United States, (1956) 51, 52-53. 
The relationship between the Commercial Code and the Code of Obligations was regulated by the following provisions of the Commercial Code:

Art. $498 \$ 1$. Legal transactions of a merchant, connected with the running of his enterprise, are commercial transactions.

Art. 499. If a transaction is commercial for one of the parties, the rules of commercial law are applicable to both parties, unless the law provides otherwise.

After World War II, both Codes have remained in force, except some provisions which were repealed. They have to be applied in the light of a new law, on the Generall Principles of Civil Law, enacted first on November 12, 1946, ${ }^{11}$ and in another version on July 18, 1950. ${ }^{12}$ This statute repealed and changed many articles of the Code of Obligations in its general part, and simply restated some others.

This statute and the Code are today the primary source of the law of contracts in Poland. However, changes are being contemplated, and the situation is not final..$^{13}$ Obligations will be covered by a civil code which is being drafted. A project prepared by the Ministry of Justice in 1947-1948 was inconsequential. In the light of comments by one of the theoreticians of the socialist law, the reason for the failure was the fact that the project attempted to improve the old system of law rather than to establish a new one, conforming to the changed conditions of the political and social structure of the state, ${ }^{14}$ and using Soviet patterns as a model in order to avoid costly experiments. ${ }^{15}$ On September 27, 1950, the Presidium of the Government decided again to instruct the Minister of Justice to take care of the

11 Dz. U. No. 67, poz. 369.

$12 \mathrm{Dz}$. U. of July 22, 1950, No. 34, poz. 311.

${ }^{13}$ For a presentation of the problem by a judge of the Supreme Court of Poland see Bachrach, "Problems of Legislation and Codification in Poland," 4 N.S., Law in the Service of Peace (1956) 85. For him, the problems "directly relevant" to legislation and codification are "the forms of the class struggle." The important considerations for legislative policy were the following: "After the rout of isolated groups of rebels, we had to cope with the resistance and active opposition of the bourgeois class, more particularly of the big landowners in the countryside and the petty bourgeoisie of the towns, which, undoubtedly less vital, was none the less bitter and dangerous. The attack launched by the class enemy was most keenly felt in those places where the result of our policy had been weakest" (at 86). "Concern for giving expression through law to the will and to the interests of the working people is shown precisely in the search for suitable juridical methods and in the form that they assume" (at 88). See also Wasilkowska, Zadania Komisji Kodyfikacyjnej, (Tasks Confronting the Codifying Commission), 12 Państwo i Prawo, No. 1 (1957). The author points out that the main idea of codification of the Polish law is the "socialist democratisation" of the law. The most recent Polish code is that of administrative procedure (Jan. 1, 1961).

14 Wolter, Prawo Cywilne, Część Ogólna (Civil Law, General Part) $46-47$.

${ }^{15}$ Id., at 48 . 
job, along with the preparation of a new criminal code. A drafting committee was appointed by the Minister, the latter reserving the chairmanship for himself. The project was ready in 1954. Discussions followed in legal periodicals and during a special meeting of jurists, organized by the Polish Academy of Sciences and the Ministry of Justice on December 8-10, 1954. The proceedings of this meeting were published. $^{16}$

During the three days of discussions, seven sessions were held. Two were devoted to the law of obligations. One dealt with the problem of performance of contracts and liability for nonperformance; the other with some questions of the law of sales. The third part of the Draft Code covered the law of obligations.

The traditionally fundamental principle of the law of obligations, that of freedom of contracting, has been omitted from the Draft Code of 1954. There was even no mention that a contract is an enforceable agreement between the parties. An obligation, according to the Draft Code, is a right of the creditor to request some performance from the debtor. The traditional principle had been preserved, with some limitations, in the project of 1948, Article 579 of which read as follows:

Within the limits settled by the law in force, and in particular by provisions on economic planning, the coming into being and the contents of contractual obligations are subject to the free will of the parties. ${ }^{17}$

The 1954 project omitted this provision. The omission was pointed out and criticized during the discussion of December 9, 1954. Professor Czachórski ${ }^{18}$ says in his paper:

It seems that the project goes too far and avoids even a most careful and general mention of the effect of intention on the creation, contents, and performance of obligations, within the boundaries set by mandatory principles of law (ius cogens), and particularly, by the rules on economic planning. The project only includes various limitations and modifications of the principle of "freedom of contracts" which is not spelled out clearly. The limitations concern primarily intercourse between entities of a socialized economy.

The lack of a general provision laying down the principle of "freedom of contracts" seems particularly unfounded with respect to relations between individuals. In my opinion, this prin-

\footnotetext{
${ }^{16}$ Materjaly Dyskusyjne de Projektu Kodeksu Cywilnego Polskiej Rzeczypospolitej Ludowej (Discussion Materials to The Draft of a Civil Code of the Polish People's Republic), 1955.

${ }^{17}$ Materjały, supra n. 23 at 184.

${ }^{18}$ Former Dean of the Law School; Vice President, University of Warsaw.
} 
ciple should not be given too great importance. However, only this principle can justify the existence ... of (some) contracts. . . . .9 $^{2}$

The Draft Code of 1954 met with criticism and was not recognized as satisfactory. On many points criticism went in the direction opposite to that of Professor Czachórski. Opinion was expressed that the Draft did not depart substantially enough from the traditional approach and did not take into account the new socialist way of life; and the Supreme Court of Poland refused to attach much importance to the rules laid down by the Draft. It held that the Draft was merely an expression of the opinions of the committee which prepared it as the best method of regulating legal institutions in a way most conforming to the social, economic, and political foundations of the present system of government. The Court added that there is no ground for believing that solutions contrary to the Draft, and resting on the presently applicable legal provisions, such as the Code of Obligations, would be repugnant to the principles of the system of government and to the purposes of the People's State. ${ }^{20}$

The work on the code continued. It was announced that about three hundred amendments to the draft were submitted. ${ }^{21}$ A new draft was made public in 1955. Howeves;, it did not become law. A new codification committee was established by a decree of August 23, 1956, composed of practitioners and thecreticians. ${ }^{22}$

In October, 1956, Gomułka took control of the government, and the tide turned against "stalinism"; this development did not exert much influence on the shaping of the rules of contract law. It is to be noted, however, that Professor Wasilkowski, Chairman of the Codification Committee, published an article on Problems of Codification, ${ }^{23}$ in which he pointed out that changes in the contents of the Polish civil, criminal, and procedural law should be made in so far as the necessities of socialist construction demand, but all formal changes should be made with great caution, in order to retain all benefits of existing statute and case law where they still. appear to be valuable. ${ }^{24}$ For some fields of law, the developments of 1956 had a marked significance. ${ }^{25}$

\footnotetext{
${ }^{19}$ In the recent issues of some Polish legal periodicals, Professors Buczkowski, Wolter and Gwiazdomorski engaged in a discussion about freedom of contracts. The last asserted that freedom in the traditional sense does not exist in Poland any more.

${ }^{20}$ Supreme Court decision of May 25, 1955; 4 Cr. 516/55, O.S.N. 3/56/70; Swięcicki, ed., Prawo Cywilne z orzecznictwem, literattırą i przepisami związkowymi (Civil Law, with Judicial Decisions, Literature, and Special Legislation), v. I, (1958) 15.

${ }^{21}$ Bachrach, op. cit. supra n. 13, at 92.

${ }^{22}$ Gross, Recent Changes in the Law and Judicial Organization of Poland, $4 \mathrm{~L}$. in Service of Peace, No. 2, (1957) 110, 112.

${ }^{23}$ In Prawo i Zycie (Law and Life) No. 19 (1958).

${ }^{24}$ Note, The Review "Law and Life" (Prawo i Zycie) 1958, 6 Rev. Contemp. L. (1959) 156, 158.

${ }^{25}$ Particularly, on the reorganization of the Bench (law of May 27, 1957). “. . .
} 
The most recent draft of the code was published in $1960 .^{26}$ It was accepted in the first reading by the Committee, and does not represent the final word of its twelve members. In the foreword, it is pointed out that a public discussion on the project is advisable now, before the final text is drafted. As in the Draft of 1954, there is no provision in the Draft of 1960 on freedom of contracting.

Some rules of specialized contract law will be left to separate legislative enactments. Thus, six drafts of a Code of Maritime Law have been prepared. The sixth version contains an introduction and six chapters: I. The Ship. II. The Owner. III. The Captain. IV. Contracts. V. Collisions. VI. Maritime Insurance. ${ }^{27}$

In spite of the fact that some provisions of the Code of Obligations have been abrogated or modified, Article 1, expressing the traditional idea, is still in force.

Obligations come into being from declarations of intention and from acts and other events which, by virtue of the law, give rise to an obligation.

Article $50 \$ 1$ of the Code, providing that "a contract comes into being by a declaration of intention of two parties to the same effect, one of them promising a consideration, and the other accepting this promise," has been replaced by a substantially similar provision of the General Principles of Civil Law: "A contract is entered into when the parties express a declaration of intention as to its material terms to the same effect" (Art. 56).

(C) hanges have been imposed by the living developments which have introduced into our judicial system an entirely new climate answering to the progressive content of the changes which occurred in Poland in October, 1956. And this new climate finds expression in the respect paid to the independence of the Bench, and the firm determination in the administration of justice to observe the strict process of law shown." Gross, op. cit. in n. 22, at 114. The Bar was reorganized by the Law of November 19, 1956. Id., at 115 .

${ }^{26}$ Projekt Kodeksu Cywilnego Polskiej Rzeczypospolitej Ludowej, 1960.

Recent Polish efforts aiming at codification were favorably appraised by some émigré legal scholars. Thus, it was pointed out that the recent trend is in the direction of making courts "the chief guardians of legality and of private rights," Grzybowski, Reform and Codification of Polish Laws, 7 Am. J. Comp. L. (1958) 393,398 , and that in the field of criminal law, because of unhappy experiences in the Soviet Union, "Polish legal thought turned to the Polish tradition" (ibid.). "The legislative techniques, the return to liberal institutions, and a realistic appraisal of the economic and social conditions of the country indicate that [The Commission's] approach will be cautious and free from doctrinal anticipation of the future in terms of legal provisions designed for some still nonexistent social structure. Hence, the emphasis on professional qualifications for members of the legal profession, whether on the bench or at the bar." Id., at 401.

${ }_{27}$ Matysik, "Podstawowe załozenia projektu polskiego kodeksu morskiego" (Fundamental Principles of the Draft Code of Polish Maritime Law), 13 Panstwo i Prawo, No. 11, (1958) 802 . 
In the Draft Code of 1960, Article 1 of the Code of Obligations has been replaced by a provision reading as follows:

Obligations are created by contracts, as well as by decisions of the state administration, by inflicting damages, by unjust enrichment and other events which, by virtue of the law, give rise to an obligation. ${ }^{28}$

The traditional limitations on the freedom of contracting, expressed in Article 55 of the Code of Obligations, have been retained:

The contracting parties may regulate their relations according to their wishes; however, the contents and the purpose of the contract cannot be contrary to the public order, the law, and good morals.

Commenting upon this provision, Wolter states that the bourgeois principle of the freedom of contracts serves as a tool for the interests of "big capital," and must give way in the system of organized economy where the anarchistic idea of free competition is replaced by socialist planning. In relation: between individuals, it must be seriously limited, particularly so as not to permit any exploitation of men by men on the capitalist pattern. So, even if Article 55 is still in force, its wording only is old, but its content is different and should be interpreted in the light of the requirements of the new system. ${ }^{29}$

Article 357 of the Draft Code of 1954 attempted to limit further the freedom of contracting by stating that an agreement will be void if it should be contrary to administrative regulations relating to the coming into being, contents, and termination of obligations.

Although Article 55 of the Code of Obligations is still in force, some of its other provisions on the same point have been replaced by articles in the General Principles of Civil Law, which brought the law more into line with the theoretical foundations of the "People's Democracies." Thus, Article 49 of the Code, stating that "an impossible condition, or a condition contrary to the public order, the law, or good morals, makes the declaration of intention void if it is a condition precedent, and is considered nonexistent if it is a condition subsequent," has been repealed, and the corresponding provision in Article 82 of the General Principles reads as follows:

An impossible condition and a condition contrary to the law or principles of common society life in the People's State nullifies the legal transaction if it is a condition subsequent.

${ }^{28}$ Art. 308.

${ }^{29}$ Wolter, op. cit. in n. 14, at 301-302. 
A new provision on the construction of declarations of intention is to the same effect. Article 107 of the Code of Obligations, reading as follows:

A declaration of intention should be interpreted in accordance with the requirements of good faith and customs of honest dealing, due account being taken of the circumstances in which it was expressed

has been repealed, and in its place Article $47 \S 1$ of the General Principles (using the terms of Article 76 of the Constitution) provides:

A declaration of intention should be interpreted in accordance with the requirements of the principles of the common society life in the People's State.

The intention of the parties is again referred to in Article $47 \S 2$ of the General Principles, which repeat, in a slightly modified phraseology, the provision of Article 108 of the Code of Obligations:

In construing contracts, the common intention of the parties and the purpose of the contract should be investigated, rather than its literal wording relied upon.

And the Supreme Court of Poland held, while Article 108 of the Code was still in force, that its provisions are applicable also to unilateral declarations of will; therefore it should be investigated what the intention of the party making the declaration was and what purpose such party had in mind. ${ }^{30}$

But in other provisions of the General Principles, the impact of the communist approach appears again. The term "common society life in the People's State" (see supra) is used in some other articles. Thus, Article 3 provides that "it is not permitted to use a right which would violate the principles of the common society life in the People's State," and Article $41 \S 1$ states that "a legal transaction contrary to the law or principles of the common society life in the People's State is invalid." Another general principle, expressed in Article 1, reads as follows: "Provisions of law should be interpreted and applied in conformity with the principles of the system of government and purposes of the People's State."

The new approach has been commented on in a recent treatise: "In spite of the fact that the principle of freedom of contracts was substantially curtailed in the socialist system of government, the parties can still freely determine the contents of obligations to a certain extent." ${ }^{31}$

${ }^{30}$ Supreme Court, decision of Aug. 31, 1948, K.C. 315/48. Swięcicki, op. cit. in n. 20 , v. 1 , at 130 .

31 Ohanowicz and Górski, Zobowiazania-Część Szczegołowa (Obligations-Detailed Part) (1959) 4. On the applicability of the Commercial Code in the new legal system, 
These broad provisions make it possible for the courts to interpret statutes as well as contracts in the way they think proper. The courts make frequent use of them, ${ }^{32}$ and thus there is always the possibility that the intention of the parties may be defeated, or that a specific statutory provision may be deprived of its effect.

As an example of the application of Article 1 of the General Principles, a case of 1950 may be cited. Contrary to common law, in cases of unlawful impairment of health and earning capacity, the Polish Code of Obligations provides for recurrent payments (like an annuity) rather than a lump sum as standard damages, ${ }^{33}$ but provides that "instead of recurrent payments the court may, for important reasons, grant a lump sum. ${ }^{34}$ Invoking Article 1 of the General Principles, the Supreme Court refused to recognize the desire to establish a business enterprise as an "important reason" for granting a lump sum. The court pointed out that the plaintiff's intention was to establish an enterprise based on capitalist principles, and referring to his contention that this was an "important reason," continued:

This position is reminiscent of ideas which grew on the background of the old economic system, the capitalist system, in the light of which ownership of one's own "economic outpost," or enterprise run on the principles of the capitalist economic system, was considered the best assurance of the financial situation of an individual. In the new conditions of the governmental system, in the social and economic system of the People's State, such a position cannot be, of course, recognized as right, and the interpretation of Art. $164 \$ 1$ of the Code of Obligations, based on ideas connected with the previous system, is untenable. . . . The purpose of the institution of compensation for unhappy accidents cannot be the creation of new capitalists.

the authors state: "In spite of the fact that the socialized enterprises are not "merchants," the possibility, and even the necessity of an analogous application of the provisions of the Commercial Code in a manner conforming to the changed relations in the system of government, as to legal transactions which they undertake, is warranted by the following considerations: ...4) Legal enactments of the People's Poland make many references to provisions of the Commercial Code concerning commercial transactions ... A proper application of the provisions of the Commercial Code means that those provisions may and should be applied, the content of which is not conflicting with the different character of the socialized enterprises and the fact that they have other, planned purposes in the People's. State." ld., at 6 .

${ }^{32}$ A summary of decisions applying these general provisions is given in Swięcicki, op. cit. in n. 20, and in Litwin, Zasady Społecznego Wspołzycia w. Orzecznictwie Sądu Najwyzszego (The Principles of the Common Society Life in the Decisions of the Supreme Court), Nowe Prawo, No. 12, (1953) 4.

${ }^{33}$ Art. 161. The same rule is applicable to damages owed to survivors for causing a wrongful death (Art. 162).

${ }^{34}$ Art. $164 \$ 1$. 
In interpreting Articles 161-166 of the Code of Obligations, and in particular, in connection with Art. 196 of the statute on social insurances, i.e. when the problem is compensation for accidents which happened at work, it should be kept in mind, first, that in the system of a people's democracy the basic source of livelihood for everyone should be the work done within the limits of the possibilities and physical and intellectual capacities of the given individual, and then, it should be taken into account that the People's State extends its protection to individuals unable to work, and in particular, to those who are disabled because of accidents at work, and grants them help." ${ }^{35}$

There are numerous cases in which the broad provision of Article 3 of the General Principles (or Article 5 of the earlier version) has been applied by the Supreme Court and lower tribunals. Thus, recognizing that the employer dismissing an employee from his job does not have to give any reasons, the Supreme Court indicated that such a dismissal nevertheless will not be treated as valid if the dissolution of the employer-employee relationship does not satisfy the social purposes of the law which protects the employee, or the requirements of good faith. ${ }^{38}$

In effect, the employer may be forced to continue the employment of a person he does not want. But Article 3 may also work against the interests of the employee. Thus, even though an employment contract, by oversight of the employer, was not formally terminated, the principles of the common society life will not permit the employee to recover his accumulated salary if he neglected to clear up the situation. ${ }^{37}$

In another case involving a labor situation, an employee's working duties and hours were changed. The Supreme Court pointed out that the employee was "a member of the team, responsible for the fulfillment of duties, assigned to a state industrial enterprise," and continued:

Therefore, it is contrary to the principles of common society life, on the part of the employee, to insist on the wording of the contract and disregarding the vital needs of the enterprise in which he works, to refuse to perform during a short, temporary period of time, duties which are fully adequate to his professional qualifications, only because those duties are not identical to the ones provided for in the contract, and in particular, because they

85 Supreme Court, decision of Nov. 14, 1950 C. 299/50-Zb. O. 1/52/11, P.i.P. 8-9/51, 436, N.P. 11/51/39, P.Z.S. 8-9/51/93, Swiecicki, op. cit., v. I, p. 16, 369.

${ }^{3}$ Supreme Court, decision of June 21,1948 , C. Prez. 114/48, Zb. O. 3/48/61, P.i.P. 9-10/48/147, P.N. 9-10/48/305, Swięcicki, op. cit., v. I, p. 22-23.

${ }^{37}$ Supreme Court, decision of Oct. 3, 1953, I C. 3031/52, P.U.G. 3/54/112, Swięcicki, op. cit., v. I, p. 32. 
lack the character of executive work, which was connected with the job contracted for. ${ }^{8}$

Some other cases involved the problem of eviction. Thus, it was held that Article 3 makes the validity of a notice of eviction from an apartment dependent on consideration of the effect of the eviction on the life of the tenant and his family, taking into account its size, the age of its members, etc., even if the statutory requisites for terminating the contract of tenancy have been met. ${ }^{89}$ The termination of tenancy of premises used for a pharmacy and a request for eviction, at a time when in the locality involved there were no other premises adequate for a pharmacy, is contrary to the principles of the common society life, is detrimental to the: community, and cannot be given effect. ${ }^{40}$

Again, the Supreme Court indicated that a suit to evict a person who had been in possession and had tilled the land for many years, necessarily raised, at the very outset, a problem of the conformance of the plaintiff's request with the principles of the common society life. In such a case, the mere statement that plaintiff has the right he is seeking to enforce will not be sufficient; it will be necessary to establish that, contrary to first impressions, in this particular case the owner does not abuse his right. ${ }^{41}$

Among other instances of invoking Article 3, there is a case in which the Supreme Court asserted that the social interest in not demolishing buildings once they are erected is so great that it takes precedence over the interest of the person requesting abatement, even if the structure was built in bad faith. ${ }^{42}$

According to the comments of one of the foremost legal writers of present Poland, the formula of "good morals," used in the traditional systems of law, is much more objectionable than the new general provisions of the communist enactments:

In bourgeois theory, the above ideas are treated as mandates of morality. But there, they amount to mere phraseology, as the characteristic feature of the exploiting class is its moral downfall. And it could not be otherwise, as the decisive goal of the bourgeoisie was' and is the striving to profit, and money is the

${ }^{38}$ Supreme Court, decision of Oct. 16, 1952, C. 1906/52, N.P. 7/53/67, P.U.G. 3/53/104, Swięcicki, op. cit., v. 1, p. 33.

${ }^{39}$ Supreme Court, decision of Mar. 13, 1956, 1 Cr. 197/56, O.S.N. 4/56/111, Swięcicki, op. cit., v. I, p. 26-27.

${ }^{40}$ Supreme Court, decision of Dec. 7, 1949, C. 1675/49, Zb. O. 1/50/22, P.i.P. 1/51/145, Swięcicki, op. cit., v. I, p. 37-38.

${ }^{41}$ Supreme Court, decision of June 18, 1954, 1 Cr. 730/54, N.P. 12/54/90, Swięcicki, ,op. cit., v. I, p. 34.

42 Supreme Court, decision of June 30, 1951, C. 704/50, Zb. O. 2/52/45, Swięcicki, op. cit., v. I, p. 36 . 
only yardstick of the value of an individual. The bourgeoisie "did not leave between men any other tie than a bare business, than a 'cash payment,' devoid of any sentiment."

The same author contends that ideas of good faith, good customs, and principles of honest dealing "make it possible for the court, because of the abstract character of those concepts, to by-pass the provisions of its own, bourgeois statute when its application is disadvantageous to the capitalist. The application of the above-mentioned criteria takes place above all in the evaluation of the means of performing contractual obligations." ${ }^{\text {"4 }}$ These criteria "are a mask for the direct goal and the moving spirit of capitalist intercourse, particularly in the period of monopolistic capitalism, which goal is the striving towards the attainment of the highest possible profit by way of exploitation, destroying and ruining the major part of the country's population." 45

In contrast to such "abstract formulas," the author asserts that the Soviet idea of "principles of the socialist common life" is "a concrete concept." "It is "based on the premises of socialist morality. . . . As categories of morals appear the concepts of good and evil, duty and justice, conscience and honor, which have general character. The application of those general principles of behavior finds its expression in the so-called principles of socialist common life, which means in socialist customs." ${ }^{47}$ The counterpart of this idea in Polish law is that of the "principles of the common society life." "48 There is no difference between those principles and the moral norms. Their reflection is, e.g., the "priority of the social interest or equalization of social with personal interests." ${ }^{49}$ According to the author, the new approach "introduced an objective evaluation of care required in socialist intercourse."

And discussing the present Polish rule on the invalidity of some legal transactions, he points out that by virtue of Article 41 of the General Principles, the following principal categories of transactions are considered as unlawful: $:^{31}$

(1) Transactions contrary to the principles of the system of government and the social and economic structure of the State, such as those which are directed against the rights of state or

${ }^{43}$ Szer, Prawo Cywilne, Część Ogólna (Civil Law, General Part) (1955) 26, citing Marx and Engels.

44 Ibid. To the same effect Wolter, op. cit., in n. 14, at 61-62.

4 Szer, id., at 173 .

${ }^{16} \mathrm{ld}$., at 26.

${ }^{47} I d$., at 27.

48 Id., at 28 .

$49 \mathrm{Id}$., at 29 .

$50 \mathrm{ld}$., at 30 .

${ }^{51}$ Id., at 206-208. 
co-operative property; repugnant to the principles of economic planning, to the economic system of accounting, to "financial discipline," or to laws regulating prices.

(2) Transactions which violate mandatory legal norms, like those which regulate the form of contracts, legal capacity of the parties, prohibiting some transactions, etc.

(3) Transactions which transgress the purposes of planned economy entities stated by the law.

As transactions contrary to the principles of the common society life in the People's State, he further enumerates those which support or enable conduct contrary to "scrcialist morality," and those which aim at by-passing the law.

Another theoretician of the present system observes that the sources of those principles are "rules of morality which are the expression of the convictions of the majority of the society, or of the working people of the towns and villages in their striving to build socialism and wind up the remnants of the capitalist structure." ${ }^{52}$ However, the principles of the common society life should not be identified with the rules of morality, "which have a general character, while the principles . . . are characterized by concreteness and their association with separate forms of social relations." ${ }^{\text {"53 }}$ In the establishment of the principles, "the leading role is played by the consciousness of the workers' class, having hegemony in the society, and being led by its avant-gardethe party." "The "most progressive part of society" is chiefly responsible for their coming into being, and then they acquire a mandatory force "irrespective of the passive attitude or even resistance of those elements which continue to represent retrogressive or clearly inimical ideas (remnants of the capitalist class)."

However, even some high authorities in Poland recognize that there is danger in those general provisions. Opening the discussions on the Draft Civil Code of 1954, the Minister of Justice Swiatkowski expressed the opinion that Articles 1 and 3 of the General Principles enable the courts to avoid the application of statutory provisions which have become obsolete, and stated that as a result some statutes become dead even if they are not repealed. He acknowledged that judicial decisions of this kind often are not uniform, which leads to the violation of the rule of law, prevents the citizens from claiming their justified rights, and causes injustice. ${ }^{56}$

In an article which appeared in a Polish legal periodical, the author criticized the attitude of some courts and complained of some deci-

52 Wolter, op. cit., in n. 14, at 63.

${ }^{3}$ lbid.

${ }^{54}$ Id., at 64 .

${ }^{55}$ lbid.

${ }^{56}$ Materjały, supra, n. 16 , at 7. 
sions which showed a danger of "legal nihilism" by a careless and mistaken application of Article 3 of the General Principles. This attitude is reflected in judicial references to the "principles of the common society life," without making clear what principle is at stake, and without any analysis of the factual situation from the viewpoint of applicable provisions of law. The author pointed out a dangerous tendency of inexperienced judges ${ }^{57}$ to supplant all law with Article 3, and appealed for an effort to make the idea of "the principles of the common society life" more concrete. ${ }^{58}$

Polish legal scholars living in the Free World are even more trenchant in their criticism. Citing some articles of the General Principles and of the Constitution of 1952, one of them states:

Thus both the law . . . and the Constitution call for a political interpretation of the law. A law should be interpreted and applied . . . in the light of the policies of the government in pursuit of the general 'purpose of the People's State.'

This brings the class war approach into the operation of law, substituting bias for objectivity. Great uncertainty is thereby created and the door is opened to an arbitrary interpretation and application of legal rules. ${ }^{58}$

As to the concept of "common society life in the People's State," which replaced that of good faith and good morals, but has a broader connotation, the author states that it "opened the door for . . . arbitrariness," and that " $(t)$ his new method of construction of contracts may always be used to the detriment of the true intentions of the contracting parties."

Another author comments:

These principles opened the way to a "free legal interpretation" of (these) general notions ... New judges duly indoctrinated, as well as the old ones forced to follow the Communist party line, were thus armed with wide powers of interpretation enabling them to give a new meaning to such basic institutions and notions as property, contract, discharge of obligations, good faith

\footnotetext{
${ }^{57}$ Many judges, appointed after World War II, did not have any adequate legal preparation.

${ }^{58}$ Rozanski, "O Błedach w Orzecznictwie Niektorych Sadow Powiatowych Przy Stosowaniu Art. 3 p.o.p.c." (On Errors in Some Decisions of County Courts in the Application of Art. 3 on the General Principles of Civil Law), 11-12 Nowe Prawo (1956) 138; Swiecicki, op. cit. in n. 20, v. I, p. 24.

${ }^{59}$ Siekanowicz, Contracts in Postwar Poland, 5 Highlights (mimeogr., Libr. of Congress, 1957) 493, 494-495, and Chapter 46 of Gsovski and Grzybowski, Government, Law and Courts in the Soviet Union and Eastern Europe, v. II, (1959) 1307, 1313.

${ }^{80}$ Id., at 495. For the origin of the phrase, modeled on the Soviet Pattern, see Szer, Prawo Cywilne, Cześć Ogb́lna (Civil Law, General Part) (1955) 26-30; Wolter, Prawo Cywilne, Cześć Ogólna (Civil Law, General Part), (1955) 60-65.
} 
and to remold them in accordance with the requirements of the so-called "socialist legality" or "socialist rule of law."

It is interesting to note that in the most recent draft of the Polish Civil Code, that of 1960, there are no provisions parallel to Articles 1 and 3 of the General Principles. However, the concept of "principles of the common society life" is referred to in some articles of the draft, imposing on legal transactions consequences resulting from those principles, ${ }^{62}$ invalidating transactions which are contrary to the principles, ${ }^{63}$ or requiring that a declaration of intention be interpreted according to the "circumstances in which it was expressed and the principles of the common society life." construing contracts, the common intention of the parties should also be investigated."

The study of the present Polish law of contracts, just as that of the law of other communist countries, should be undertaken with the effect of those general principles in mind. Their application may have a bearing, in a concrete factual situation, on the effect of specific, seemingly neutral rules such as those dealing with offer and acceptance.

Another point should be made. Until now, only some provisions of pre-war statutes have been repealed; others are still in force. The Supreme Court of Poland has made clear ${ }^{88}$ that they were retained by the will of "the people's legislator," are a part of the legal system of the "People's Poland," and must be abided by, unless they are repugnant to the principles of thi: system of government or to the purposes of the People's State. ${ }^{67}$

The question arises whether, and to what extent, judicial decisions from the prewar period are good authority in Poland today. This problem was discussed by the Supreme Court of Poland in 1948, and the following resolution was carried at a plenary session of the Court:

Whereas . . . a distinction should be made, from the viewpoint of the present system of government, between those judicial decisions and legal principles, laid down in the period between the two wars, which are still applicable, and those which are inapplicable, because of the fundamental revamping of the Polish State as authorities for current judicial decisions of Polish courts,

B1 Nagórski, "Draft of a New Civil Code for Poland," in Studies of the Association of Polish Lawyers in Exile in the United States, v. I, (1956) 51, 57.

62 Art. 47.

${ }^{63}$ Art. $49 \S 1$.

${ }^{64}$ Art. $54 \$ 1$.

${ }^{65}$ Art. $54 \$ 2$.

${ }^{06}$ Supreme Court, decision of Dec. 5, 1950, C. 323/50, 8-9 Państwo i Prawo 420 (1951); S.N. June 30, 1951, C. 649/50, Zb. O. 2/52/44, 2 Państwo i Prawo 312 (1952); Swiecicki, op. cit., v. I, p. 12.

${ }^{\circ}$ See Art. 1 of the General Principles of Civil Law, supra. 
The Plenary Session of the Supreme Court resolves:

1) To recognize ... that the decisions of the Supreme Court and the legal principles from the period between the wars (19181939), which are repugnant to the present system of government and the statutes which are in force, have today only a historical meaning.

2) To state that only those judicial decisions and legal principles from the above period between the wars are still good law which do not contain this repugnancy.

3) To entrust the evaluation of a given judicial decision or legal principle and its classification under the first or second point of the present resolution, to the several judges sitting in the case, the question whether this evaluation is well founded being subject to the normal control by higher courts. ${ }^{68}$

In spite of this resolution, the courts and authors are rather reluctant to cite any pre-war Polish judicial decisions.

With the above reservations, the legal rules concerning contracts between individuals, in force in Poland (as in other communist countries), are comparable to the corresponding rules in the traditional legal systems. Even though the principle of freedom of contract is not expressly recognized, the parties will be permitted to regulate relations between them substantially according to their will so long as the state is not interested in the subject matter of the agreement.

\section{Contracts between Socialized Economic Units}

It is conceivable to regulate the whole economic life of a country and the relations between its industrial and commercial enterprises by a set of governmental decrees and ordinances, without any room for negotiations between the entities involved. As a matter of fact, such a system once was tried in Russia, but it did not work. Even the planned economy theoreticians admit that it was never carried out in a pure form, as "it fails in the light of the impossibility of eliminating the influence of the law of values." On the other hand, the economic system of Yugoslavia is based on a fairly free market; the difference between a "capitalist" system and this type of a socialist regime lies mainly in the nature of the ownership of enterprises. ${ }^{30}$ The most common type of socialist system is the one in which the eco-

${ }^{68}$ Plenary Session of the Supreme Court of Nov. 25, 1948-3 Państwo i Prawo 120 (1949), 12 Demokratyczny Przeglad Prawniczy 58 (1948), 3-4 Przeglad Notarjalny 184 (1949), 4 Przeglad Ustawodawstwa Gospodarczego 84 (1949), Swiecicki, op. cit. in n. 20, v. I, p. 11-12.

09 Buczkowski, Zagadnienia Prawe "Modelu" Gospodarki Socjalistycznej (Legal Problems of a "Model" Socialist Economy), 13 Państwo i Prawo, vol. I, (1958) 786, 790.

${ }^{70}$ lbid. 
nomic life of a country is based on a curious set of rules-a blend of administrative and contract law, the first one prevailing in relations between the socialized enterprises and the superimposed co-ordinating agencies of the state, while the cother (i.e. contract law) governs the relations of the entities inter sese. ${ }^{11}$ However, as will be seen, this contract law has a special flavor, unknown in the traditional legal systems.

The application of all general :ules of contract law to the contracts of government-owned enterprise:; is hardly conceivable. True, many provisions of the pre-war Code of Obligations have been retained, and they cannot be simply forgotten in establishing the consequences of "contracts which are the creation of socialist economy"; but they must be viewed in the light of Article 1 of the General Principles of Civil Law, and before they can be relied upon, an inquiry must be made in each instance as to whether they should be applied in the changed situation. ${ }^{72}$

In Poland, as in other communist countries, special rules have been enacted as to contracts between socialized economic units and as to the method of settling disputes which may arise between them. In seeking to draw conclusions as to similarity or dissimilarity between this set of rules and the contract law of non-communists countries, we must proceed with caution. Comparison limited to some detailed rules may reveal that some of them are similar; a civil-law relation may be said to exist between "socialist organizations" or enterprises, "even if one of them did not want to conclude a contract with the other and was compelled to do so by a decision of an arbitration commission"; ${ }^{33}$ but it does not follow that the institutions under consideration are comparable. In the traditional legal systems there is no planned economy; the business life of the nation rests, by and large, on private initiative. Of course, there may be contracts with the state; but, then, the general principles of contract law will be applicable. ${ }^{74}$ "The law of contracts, as the West knows it, is an instrument of a liberal society and a free market economy."

The very fact that in the cornmunist countries there is a special branch of the law, dealing with planned economy contracts (even if it may be embodied in a general civil code), while other rules are applicable to transactions between individuals, furnishes some evidence that this branch is a new one, having no counterpart in the law of other countries; it comprises situations which may arise only in the

${ }^{71}$ Ibid.

${ }^{72}$ Supreme Court, decision of May 25, 1955, Cr. 516/55, O.S.N. 3/56/70; Swiecicki, op. cit. in n. 20, v. I, p. 14.

${ }^{73}$ Mihaly, The Role of Civil Law Institutions in the Management of Communist Economies; The Hungarian Experience, 8 Am. J. Comp. L. (1959) 310, 311.

${ }^{74}$ However, some specific rules applicable to the details of the transaction may be different from those prevailing in other contracts.

${ }^{75}$ Mihaly, id., at 310. 
communist systems. Of course, sometimes the rules in force in both situations may be the same. Thus, the Czechoslovak Civil Code of 1950, speaking of "liabilities arising from the exercise of the unified economic plan" provides in Sec. 212 (2) that "in the absence of any other provision the legal relations which come into being in this manner shall be ruled by this law." Even so, the application of the rules may be different. The most important object of planned economy contracts will be to carry out the plan, not to give effect to the intention and expectation of the contracting parties, ${ }^{76}$ which usually will be instrumentalities of the state."

In recent years, in the Soviet Union and other communist countries there have been frequent discussions whether the general civil code should regulate only relations between private individuals, leaving all problems relating to state enterprises to be dealt with by special enactments, or whether some provisions of the civil code should be applicable in all kinds of transactions. By now, the trend is definitely settled in the latter direction.

In July, 1960, a project of "Bases of civil law and civil procedure" was published in Moscow. After discussion, it may be adopted as lawin original or amended form-by the Supreme Soviet. The "Bases" will serve as the starting point for civil codes and other legislation in the several states of the Soviet Union, and will undoubtedly exert a strong influence on the law of other communist countries. Article 2 of the Project provides that

by civil legislation are regulated relations ...

between the citizens, with each other

between the citizens and state, co-operative and social organizations,

between state, co-operative and social organizations with each other. $^{78}$

The Polish Draft Code of 1960 follows the same pattern, and in theory attempts to merge the "economic law" with the general civil law. The foreword states that the Code is based on the concept of

76 "Even when there is a superficial similarity of rules, it is clear that the social function of a contract between two plan-fulfilling state enterprises, operating without reference to a market, is quite different from that of a contract in a society in which the bargaining of individuals and groups provides the principal mechanism for giving effect to their own wishes and preferences ... In functional terms, the comparability of a free contract and of a contract bteween plan-fulfilling state enterprises is highly problematic." Schlesinger, op. cit. supra n. 6, at 69.

77 "The director of an enterprise, its leaders, and the 'work-collectives' are actually not the enterprise's master; they are executors of mandatory plans." Mihaly, op. cit. in n. 73 , at 327.

${ }^{78}$ See Fridieff, "A propos des projets de 'Fondements de la législation civile de l'U.R.S.S. et des Républiques fédérées' et de 'Fondements de la procédure civile de l'U.R.S.S., et des Républiques fédérées," 13 Rev. Int. de Droit Comparé (1961) 91, 92-93. 
unity of civil law, as it "regulates civil law relations between individuals, between socialist and non-socialist organizations, and between individuals and organizations." "However, the structure of economic organizations is not covered, and the very applicability of the Code to them is limited to situations "not regulated in another way by special statutes and provisions issued by competent agencies" of the administration. ${ }^{80}$ Thus, as to those organizations, the Code would have only a "subsidiary role." To this, there were objections on the part of some members of the drafting committee itself. ${ }^{\text {.1 }}$ It was decided to make a final decision on this point after public discussion of the problem. To this discussion, on this and on other questions-the committee "attaches a tremendous importance." moreover, that the Draft Code of 11960 contains a number of provisions applicable only to contracts between socialist organizations; these provisions appear in a separate part of the draft. ${ }^{83}$

The author of a leading recent treatise on obligations commented:

The most important (problems) concern obligations of planned economy units. Principles in accordance to which regulations of these legal relationships must: take place are essentially different from principles of obligations in the approach of the Code of Obligations as a statutory enactment dating back to the pre-war period, because the foundations of statutory enactments of the socialist type which regulate transactions between the entities of planned economy are different from the traditional premises of the law of obligations in the capitalist period. ${ }^{84}$

\footnotetext{
io Art. $1 \S 1$.

80 Art. 1 \$2.

${ }^{81}$ Foreword to the Draft, at 4.

82 Id., at 5 .

${ }^{83}$ See Appendix I.
}

${ }^{84}$ Ohanowicz, Zobowiązania-Część Ogólna (Obligations-General Part) (1958) 4. Prof. Katzarov, in his article on "La Planification comme Problème Juridique," 10 Rev. Int. Dr. Comp. (1958) 298, pointed iout that economic planning established some "new legal institutions," and in particular, a "super-source" of the law of obligations, which is the economic plan. The aim of this "super-source" is "improvement and limiting of the rule of nullity of classical law in order to obtain a change, and not a nullity, of all rights and obligations which hinder the carrying out of the plan" (at 309). He states that the new system could bring about "the replacement of contract law by administrative law, and of the contract by the administrative order." However, this approach was not adopted. Along with the nationalization and socialization measures, some private law activity was reserved for the state enterprises which have a personality separate from that of the state. Therefore, the economic plan as a "super-source" of the law of obligations "can modify or annul legal or contractual relations, but only under the condition (1) that these relations are repugnant to the carrying out of the plan, and ... only during the time (2) and to the extent (3) that it will appear necessary for the carrying out of the plan. ... It follows that the elevation of the economic plan of the State to the level of a source of obligations is a new phase of the penetration of public law into the field of contractual law, especially in relations between state enterprises ..." (at 310). It also follows that "the economic plan . . becomes a 
The Polish Minister of Justice stated in 1954 that the socialist legal institution called "contractation" is one of the principal forms of carrying out the economic union between town and country, although it is unknown in the traditional legal systems. ${ }^{85}$ The same observation is applicable to other types of planned economy contracts.

The basic law relating to these contracts was the Statute of April 19,1950 , on planned contracts in a socialized economy. ${ }^{86}$ The statute was supplemented by an executive order of the Chairman of the State Commission for Economic Planning of May 15, $1953 .^{87}$

Contrary to the principles of the traditional law of contracts which do not impose upon anyone a duty to enter into contractual relations except in rare situations, Art. 2 of the above statute required the state enterprises and those controlled by the state to conclude planned agreements in order to fulfill their duties in the carrying out of the economic plan. This provision, understandable in the system of law in which it was enacted, illustrates well the main difference between the two fields of contract law. The Chairman of the State Commission for Economic Planning establishes a list of superior economic institutions which enter into general agreements, ${ }^{88}$ while lower units conclude detailed agreements between themselves (Art. 7). Direct contracts, without general agreements, are possible in some cases (Art. 10).

The statute expressly required planned economy contracts to conform to the economic plan of the state and to the interests of the national economy (Art. 18). If these considerations should be violated, the State Arbitration Commission may modify the contracts, or even declare them altogether invalid (Art. 20). No disputes relating to planned economy contracts are adjudicated by the courts. They must be submitted to arbitration, in accordance with statutory procedure.

Some of the provisions of the statute have been incorporated, with or without changes, in the Draft Code of 1954. Many provisions of the statute itself have been criticized, and it was replaced by the decree of May 16, 1956, on Delivery Contracts Between Socialist Economic Units. ${ }^{89}$ The new law of course had the same objectives as the old one, and did not introduce any departure from the general approach to contracts in a planned economy system. Article 1 of the decree laid

source of contractual law to which the real contractual law, created by the contracting parties, is subordinated. All that, in a contract, is out of harmony with the economic plan ... must be rectified or declared null" (at 311).

${ }_{85}$ Materjaty, supra n. 16, at 6 . For provisions on contractation in the Draft Code of 1960, see Appendix II.

${ }^{86} \mathrm{Dz}$. U. No. 21, poz. 180 (1950).

${ }^{87}$ Mon. Pol., Order 28/1953, poz. 109.

${ }^{88}$ Such general agreements or contracts are favored in the Soviet Union and most other planned economy states. However, "the introduction of the general contract did not meet with much success in Hungary." Mihaly, op. cit. in n. 73, at 317.

${ }^{89} \mathrm{Dz}$. U. of May 30, 1956, No. 16, poz. 87. 
down the rule that relations between socialist economic units are based on contracts, but, naturally, compulsion to enter into agreements and other incidents of planned economy had to be retained. ${ }^{90}$ It seems, however, that under the decree, the rules of the Code of Obligations are more readily applicable than under the former statute. ${ }^{91}$ The decree has been supplemented by an executive order of the Chairman of the State Commission for Economic Planning of October 15, 1956. ${ }^{92}$

The new law contains no provisions constituting a direct counterpart of articles 7 and 10 of the old one. One of the articles provides for the possibility of making contracts by administrative orders:

In exceptional cases, warranted by economic necessity, the Council of Ministers may authorize the head organs of the state administration to issue orders directing the subordinate socialist economic units to make deliveries to other socialist economic units without a contract having been concluded between them. These orders create rights and duties for the recipient and the purveyor in the same way as if a contract were entered into between them. ${ }^{03}$

As an interesting example of the ways in which transactions between private individuals differ from those between socialist organizations, the question of sellers' and buyers' obligations in sales transactions may be cited.

One of the papers read during the 1954 discussion on the Draft Code dealt with the provisions on sales, and a lively exchange of views followed. According to the traditional approach, "a contract to sell goods is a contract whereby the seller agrees to transfer the property in goods to the buyer for a consideration called the price," ${ }^{4}$ while a sale is an agreement whereby the seller presently transfers the property to the buyer. ${ }^{95}$

In communist countries all important enterprises are state owned, and their property belongs to the state. This makes it difficult to speak of a transfer of title. How can these be a sale, in the traditional sense, if both parties are agents of the same principal, and if sales transactions are not subject to the free will of the parties, but are mandatory, and if their subject matter is not the transfer of ownership from the seller to the buyer? This is the answer given by one commentator:

This type of sale . . . is just: a public or social function having for its sole purpose to implernent the economic plan. These "con-

${ }^{90}$ Art. 2.1 reads as follows: "The Socialist Economic Units have the obligation to enter into delivery contracts having as purpose the fulfilment of planned purposes."

91 Siekanowicz, op. cit. in n. 59, at 501 .

${ }^{92}$ Mon. Pol. of Nov. 2, 1956, No. 89, poz. 1016.

${ }^{93}$ Art. 7.

94 Uniform Sales Act, Sec. 1 (1). However, the moment of passing of title may be different in various legal systems.

${ }^{96}$ ld., Sec. 1 (2). 
tracts" are the typical planned ones and the parties, who are in duty bound to make them and to abide by them have practically no possibility of deciding on their contents. They are dictated by the economic plan, by numerous administrative regulations and, finally, fixed in full details by "model contracts" prepared and issued by the proper authorities.

In connection with this, provisions concerning the sale price will seem interesting:

(1) The settled prices on the day of the delivery will be applicable.

(2) The parties cannot fix the prices in a contractual way, except in cases where they were authorized to do so in regulations concerning the prices. ${ }^{97}$

The Draft Code of 1954 drew a distinction between sales in the traditional sense and those between planned economy units. In the first situation, the Draft Code substantially repeated Article 294 of: the Code of Obligations (which is still in force) by providing that by a sales contract "the seller obligates himself to transfer to the buyer the ownership of the goods, and the buyer obligates himself to pay the price ${ }^{38}$ (italics added). Article 294 of the Code of Obligations included in the definition the sale of a property right, while in the Draft Code there is a separate article on that point, ${ }^{80}$ making rules on the sale of: goods applicable to the "sale of rights," the word "property" being omitted.

On the other hand, Article $456 \S 2$ of the Draft Code of 1954 provided that "by a sales contract between state enterprises the seller obligates himself to deliver the goods to the buyer and the buyer obligates himself to pay the price" (italics added).

The duality of the definitions of sale was criticized ${ }^{100}$ on the ground that the latter definition unduly restricted the duties of the seller and that the old approach of the Code of Obligations was flexible enough "to be fully applied in different types of sales which take place in socialist transactions." also various rights, like literary property or patents, may be the subject matter of a sale. Even if so, and even if transactions between socialized enterprises should be called sales, they certainly are sales of a peculiar kind, having no counterpart in the traditional legal systems. In spite of their peculiarities, however, these transactions are called sales in

${ }^{96}$ Nagórski, op. cit. in n. 61, at 75.

${ }^{97} \$ 54$ of Enclosure 2 to the Executive Order of Oct. 15, 1956, supra, n. 92.

${ }^{98}$ Art. $456 \$ 1$.

${ }^{90}$ Art. 468.

${ }^{100}$ Nowakowski, Materjały, supra, n. 16, at 289.

101 Id., at 288. 
the communist countries, and some incidents of the traditional sales law are applicable to them.

The Draft Code of 1960 retained the duality of the definition of a sale set in the Draft of 1954. Article 456 of the Draft of 1960 reads as follows:

$\$ 1$. By a contract of sale the seller obligates himself to transfer to the buyer the ownership of the goods and to deliver the goods to the buyer, and the buyer obligates himself to take delivery of the goods and to pay the price to the seller.

$\$ 2$. In sales between state organizations the seller obligates himself to deliver the goods to the buyer and to leave them to his exclusive disposition, and the buyer obligates himself to take delivery of the goods and to pay the price to the seller.

But not all planned economy contracts are concluded between state owned enterprises. Some of them have as parties socialized economy units on one side, and private individuals on the other. A typical contract of this kind is called, strictly following the Russian pattern, ${ }^{102}$ "contractation" (see supra). The subject matter of this contract is the compulsory sale of farm products to the state. The producer is not permitted to place all his products on the open market. The producer may be either an individual or a socialized economic unit. ${ }^{10}$

Detailed analysis of planned economy contracts in Poland would require a special study. Only a small part of such a study would cover points which can be stated in the language of traditional contract law. A system of these contracts exists in all communist countries, with different variations. There is no counterpart in the traditional legal systems.

Disputes involving planned economy contracts escape jurisdiction of the general courts and are submitted to arbitration, following the pattern of the Soviet Union, accepted in other communist countries. ${ }^{104}$

\section{General Conditions of Delivery of Goods}

An additional source of Polish, and more generally, of communist contract law, particularly in the field of sales, is a document drafted

102 Nagórski, op. cit. in n. 61, at 73.

${ }^{108}$ Details may be gathered from the translation of the pertinent provisions of the Draft Code of 1960, infra Appendix II. For a discussion in English of this type of contracts, see Siekanowicz, op. cit. in n. 59, 502-505.

104 See Grodecki, "State Economic Arbitration in Poland," 9 Int. \& Comp. L.Q. (1960) 177. For the distinction between judicial and arbitral procedure, see Tyczka, Droga Postepowania Arbitrazowego (The Way of Arbitration), Państwo i Prawo (1955) 588. In general, the most important function of arbitration in socialist countries is the enforcement of the economic plan. By arbitration it is possible "to modify or annul existing contractual relations, or else to provide for the creation of such relations, in other words the conclusion of contracts between the various enterprises, or between them and the state itself." Katzarov, op. cit. in n. 84, at 313. 
in 1957 (signed on December 13) and applicable to contracts of sale concluded on or after January 1, 1958, between the foreign trade organization of the member states of the Council for Mutual Economic Aid. Seven planned economy countries are parties to this agreement, called "General Conditions of Delivery of Goods": Albania, Bulgaria, Czechoslovakia, the German Democratic Republic, Hungary, Poland, and the U.S.S.R.

The General Conditions constitute a unification of the law of sales in transactions between the above-mentioned countries. They are based on experience gained in previous bilateral agreements between the communist states, ${ }^{105}$ and are applicable unless the parties should agree that "because of the specific nature of the goods and/or special characteristics of its delivery a departure from particular provisions . . . is required." ${ }^{106}$

Like similar projects prepared by the Rome Institute for the Unifcation of Private Law and by the Hague Conference, the General Conditions do not purport to replace the municipal law of the participating states, and are applicable only in foreign trade. The legal nature of the General Conditions is not quite clear. Some legal writers consider them as an international multilateral treaty, some othersas mere recommendations, ${ }^{107}$ as they were not agreed upon and duly ratified according to procedures followed in international conventions.

Following the usual communist pattern, the General Conditions provide that "all disputes which may arise out of or in connection with the contract shall be subject to consideration by arbitration, the jurisdiction of general courts being excluded, in an arbitral tribunal established for such disputes in the country of the defendant." However, if the parties agree, the dispute may be submitted to an arbitral tribunal of a "third Member-Country of the Council for Mutual Economic Aid." 103

It is to be noted "that each of the countries of planned economy has a permanent foreign trade arbitration tribunal which is in many respects like a court." could easily be applied to transactions between "capitalist" countries. True, economic planning and specialization prevail among the entire group of the signatories; but this is not reflected in the "Conditions." The situation is hardly comparable to that in the internal systems of

\footnotetext{
${ }^{105}$ Berman, "Unification of the Contract Clauses in Trade Between Member-Countries of the Council for Mutual Economic Aid," 7 Int. \& Comp. L.Q. (1958) 659. The text of the General Conditions is taken from this article. See also Bystricky and Landa, The Unification of Laws on International Sale, 6 Rev. Contemp. L. (1959) 67.

${ }^{100}$ Preamble to the General Conditions.

107 Bystricky and Landa, id., at 73.

$108 \$ 65$.

109 Berman, op. cit. in n. 105, at 664.
} 
these countries, where the ministries, various commissions, and other agencies of a well-developed appar:atus of bureaucracy are directing and controlling the whole economic life at every stage and at all times.

In concluding, it should be pointed out that in the private sector the rules of the Polish law of contracts do not essentially differ from the law of other traditional systems of law, with the exception of some general clauses which, if abused by the courts, can thwart the principles of other statutory provisions. However, in the sector of transactions between the socialist enterprises, a special set of rules has been developed. Even though some of them may in terms be similar or exactly the same as those in the private sector (and may, indeed, be incorporated by reference), the whole set constitutes a separate branch of the law which lies outside of the law of consensual obligations. It must be doubted whether such a set of rules can fruitfully be compared with rules and principles traditionally governing agreements among individuals which are the result of bargaining in a free market. On the other hand, it might be interesting and useful to compare the law of contracts between socialist enterprises with Western institutions in which the elements of freedom and of bargaining are limited or nonexistent, such as contracts resulting from Kontrahierungszwang, or perhaps government contracts in some of the Western countries.

\section{APPENDIX}

\section{Contracts Between Socialist Organizations in the Polish Draft Code of 1960}

Art. 343. Socialist organizations have the obligation to coöperate with each other at the conclusion of the contract as well as in its performance, having in mind the effect of their conduct on the performance of the contract by the other party, on the adequate satisfying of the needs of economic life, the keeping down of the costs of production and intercourse, and protecting the national economy against losses.

\section{Part IV. Duty to enter into contracts between socialist organizations}

Art. 358. If relevant statutory provisions imposed upon a specific socialist organization a duty to enter with another socialist organization into a contract for supplies or for some other performance with the simultaneous fixing of the subject matter of the contract and the period of time during which the contract is to be concluded, the other party has a claim to conclude this contract.

Art. 359 . $\$ 1$. If the organization obligated to conclude a contract refuses to accept the offer submitted by the organization entitled to the contract, the latter organization may ask the state arbitra- tion commission to set the contents of the contract (a pre-contract dispute).

$\$ 2$. The claim to conclude a contract lapses if the organization entitled to the contract fails to make an offer in due time, and in case of a refusal to accept the offer by the organization obligated to conclude a contract, if it does not bring a precontract dispute within fourteen days after it receives the refusal.

Art. 360. The provisions of the foregoing article are adequately applied in a case where an obligation to conclude a contract is imposed on both socialist organizations. 
Art. 361 . $\$ 1$. If the socialist organization obligated to conclude a contract accepts the offer making reservations as to its particular provisions, it should state the contents of its reservations in a statement about the differences and send the statement without delay to the organization which submitted the offer.

$\S 2$. If the organization which received the statement about the differences does not agree with the reservations pointed out therein, it may set a precontract dispute within fourteen days. Otherwise, after the lapse of that time, it is considered that a contract is concluded on terms stated in the statement of differences.

Art. 362. If the socialist organization obligated to conclude a contract does not reply to the offer submitted to it, its silence is considered as acceptance of the offer. In such a case, a contract is considered as concluded after the lapse of fourteen days from the receipt of the offer.

Art. 363. If the socialist organization to which another socialist organization submitted an offer is not obligated to con- clude a contract, it should notify the offeror about it without delay after the receipt of the offer; otherwise it will be liable for damages.

Art. 364 . $\$ 1$. If on the ground of relevant provisions an obligation to make some definite performance for a socialist organization was imposed on another socialist organization, a relationship of right and obligation between these organizations comes into being, to which relevant provisions on contractual obligations are applicable.

$\$ 2$. In case of doubt it is understood that the decision imposing on a definite organization an obligation to perform for another definite organization raises only an obligation to conclude a definite contract.

Art. 365. The provisions of the foregoing articles are applicable accordingly in a case where an obligation to change or to rescind a contract which has already been concluded, or to change or desist from performing an obligation arising from an existing relationship of right and obligation has been imposed on a socialist organization.

\section{Part XII. Contractation}

Art. 528. $\$ 1$. By a contract of contractation a person running an agricultural, gardening or breeding farm (the producer) obligates himself to produce and supply to a socialist organization (the contracting party) a definite amount of agricultural or breeding products of a definite kind, and the contracting party obligates itself to take delivery of these products on a date agreed upon, to pay the price agreed upon and to make additional definite performances if the contract or particular legal provisions stipulate for the obligation of making such performances.

$\$ 2$. Legal provisions concerning the sale at prices settled, maximum or consequential, are applied accordingly.

Art. 529. If the subject matter of contractation is to be produced on a farm run jointly by several persons, the responsibility of those persons to the contracting party is joint and several.

Art. 530. Additional performances on the part of the contracting party may be, in particular:

1) to assure to the supplier a possibility to get some definite means of production and to receive financial help;
2) agrotechnical and zootechnical help;

3) financial premiums;

4) premiums in specie.

Art. 531. A contract of contractation should be concluded in writing.

Art. 532. $\$ 1$. The contracting party is entitled to supervise and control the performing of the contract by the producer.

$\$ 2$. The extent and the way of exercising supervision and control by the contracting party are set by general conditions of contractation included in executive orders issued by the Council of Ministers or by a state administrative organ authorized by it, and in default thereof, by the contract of contractation.

Art. 533. \$1. The producer is obligated to supply at his own cost the subject matter of the contractation to a point of delivery set by the contracting party for the area of the township in which the farm of the producer is located.

$\$ 2$. If the point of delivery is at a long distance from the township in which the farm of the producer is located, the contract of contractation may impose a part of the costs on the contracting party. 
Art. 534. If after the conclusion of the contract of contractation new provisions were issued which provide for additional performances on the part of the contracting party to a greater extent than the ones which were stipulated in the contract, the contracting party should perform to the extent set in those provisions.

Art. 535. If the subject matter of the contractation is divisible, the contracting party cannot refuse to accept a partial performance, unless the contrary was provided for.

Art. 536. To the warranty against physical and legal defects of the subject matter of contractation, provisions about sales warranty are applied respectively with this difference, that the right to rescind the contract because of physical defects is available to the contracting party only where the defects are material.

Art. 537. If because of circumstances for which neither party is responsible the producer cannot supply the subject matter of the contractation, he is only obligated to refund the money advances which were received.

Art. 538. If the contract of contractation imposes on the producer an obligation to give notice, within a settled time, of the impossibility to deliver the subject matter of the contractation because of circumstances for which he is not responsible, the nonfulfillment of this obligation by the fault of the producer bars him from invoking these circumstances.

Art. 539. \$1. Reciprocal claims of the producer and the contracting party lapse within two years from the performance by the producer, and if the producer did not perform-from the day on which he was supposed to perform according to the i:ontract.

$\S 2$. If performance was made in installments, the time of limitation runs from the day on which the last installment performance was made.

Art. 540. If after the conclusion of the contract of contractation the farm of the producer was transferred into possession of another person, the rights and obligaions arising from this contract pass to the new possessor. However, this does not apply in a case where the farm was transferred for a consideration, and the trans:eree did not know about the contract of contractation and could not learn about it in the regular course of transactions.

Art. 541. $\$ 1$. If after concluding the conract of contractation the producer contributed the farm that he possessed as his share in an agricultural producing cooperative, the co-operative acquires the rights and obligations of the producer, unless the condition of the farm does not permit it.

$\$ 2$. If the condition of the farm of the producer at the time of his joining the co-operative does not permit the performance of the contract of contractation by the co-operative, the contract lapses, and the producer is obligated to refund the money advances that were received; he has the obligation to return other advantages arising from this contract to the extent they were not used for the purpose of performing the contract.

$\$ 3$. If after joining the co-operative the producer makes an individual collection of the crops which were contracted away, he bears exclusive responsibility for the performance of the contract of contractation. 